\title{
CAll helps tumor endothelial cells survive in a lactic acid-rich environment
}

Dorcas A. Annan

Nako Maishi

Tomoyoshi Soga

Randa Dawood

Cong Li

Hiroshi Kikuchi

Takayuki Hojo

Masahiro Morimoto

Tetsuya Kitamura

Mohammad Towfik Alam

Kazuyuki Minowa

Nobuo Shinohara

Jin-Min Nam

Yasuhiro Hida

Kyoko Hid

\section{Video Byte}

Keywords: CAll, carbonic anhydrase 2, tumor, blood, endothelial cell, lactic acid, microenvironment, tumor endothelial cells, mass spectrometry, pH, cancer, angiogenesis, blood vessel, Hokkaido University

Posted Date: October 29th, 2020

DOl: https://doi.org/10.21203/rs.3.rs-100310/v1

License: (c) (i) This work is licensed under a Creative Commons Attribution 4.0 International License.

Read Full License 


\section{Abstract}

Cancer cell growth depends on the production of new blood vessels by tumor endothelial cells in a process called angiogenesis. But the growing cancer cells produce large amounts of lactic acid as a byproduct of glucose breakdown. How tumor endothelial cells are able to survive in this toxic environment is unclear. In a recent study, researchers sought to uncover the mechanism of tumor endothelial cell survival in a lactic acid-rich tumor microenvironment. Using genetics and proteomics, they compared the RNA and protein levels of pH-regulating proteins in tumor endothelial cells to those in normal endothelial cells. They found that carbonic anhydrase 2 (CAII), an important pH regulator, was elevated in tumor endothelial cells, which was induced through the VEGF signaling pathway. Blocking CAll in tumor endothelial cells decreased cell survival in lactic acid conditions, and treating tumor-bearing mice with a CAll inhibitor had decreased lung metastasis. Although CAll inhibition alone did not reduce angiogenesis, the results suggest that targeting $\mathrm{pH}$ regulators like CAll may help enhance the efficacy of antiangiogenic drugs, producing powerful combination therapy to fight cancer. 